\title{
MISKONSEPSI SISWA SD PADA MATERI PHYSICAL PROCESSES: SEBUAH STUDI KASUS
}

\author{
Yogi Kuncoro Adi dan Ndaru Mukti Oktaviani \\ Pendidikan Guru Sekolah Dasar, Universitas Kuningan \\ 1yogi.kuncoro.adi@uniku.ac.id, ${ }^{2}$ ndaru.mukti.oktaviani@uniku.ac.id
}

\begin{abstract}
Understanding the concept has a vital role in the scientific literacy of primary school students. The qualitative case study used in this study as a method to reveal the misconceptions types of primary school students in science, especially Physical processes. The results show that primary school students have a variety of misconceptions in forces, floating-sinking, light, electricity and magnetism, and the Earth and space. Based on the findings of the study, further research is recommended to understand student learning processes and misconception's remediate using cognitive conflict.
\end{abstract}

Keyword: misconception, physical processes, cognitive conflict

\section{PENDAHULUAN}

Belajar adalah proses konstruksi pengetahuan, baik secara individual maupun sosial (Zhou, 2010). Hal tersebut dapat diartikan bahwa, di satu sisi seorang siswa mengkonstruk pengetahuannya secara mandiri dalam proses berpikir, dan di sisi lain dapat juga melalui interaksi sosial baik dengan teman sebayanya maupun dengan orang dewasa. Konstruktivisme individu mengacu pada karya Jean Piaget, sedangkan konstruktivisme sosial mengacu pada karya Lev Vygotsky. Bagaimanapun, keduanya turut serta dalam membangun kajian tentang konstruktivisme dalam pembelajaran IPA.

Peran konstruktivisme dalam pembelajaran IPA sangatlah penting. Seperti disampaikan (Tippett, 2010) bahwa ketika seseorang berusaha memahami dunia, mereka mengembangkan struktur pengetahuan pribadi. Hal tersebut dapat dimaknai bahwa pemikiran setiap siswa selalu aktif dan tidaklah pasif. Konstruktivisme menolak tabula rasa karena siswa memiliki potensi dan dengan potensi-nya itu mereka selalu berkembang. Dengan memahami hal itu, diharapkan pengembangan pada pembelajaran dan/atau pendidikan IPA dapat membantu siswa untuk meng-konstruk pengetahuannya. 
Tujuan penting dari pendidikan sains adalah untuk membantu siswa mengembangkan pemahaman tentang konsep dan menggunakannya ketika memecahkan masalah dalam situasi baru (Celikten, Ipekcioglu, Ertepinar, \& Geban, 2012). Oleh karena itu, pemahaman konsep yang dimiliki siswa perlu dikembangkan agar tidak terjadi miskonsepsi. Selain itu, kemampuan memahami konsep akan berdampak pada kemampuan yang dibutuhkan berikutnya, seperti memecahkan masalah. Hal ini mengindikasikan bahwa ada keterkaitan antara konstruksi pengetahuan baru dan pengetahuan sebelumnya pada siswa. Jika pada pengetahuan sebelumnya siswa memiliki miskonsepsi, akan menyulitkannya untuk mempelajari pengetahuan baru.

Selama beberapa dekade terakhir, para pendidik sains telah sepakat bahwa para siswa memulai pelajaran tentang sebagian besar topik sains dengan konsepsi pra-instruksional yang berbeda dari konsepsi ilmiah. Konsepsi-konsepsi ini, yang disebut konsepsi alternatif atau miskonsepsi, kuat dan tahan terhadap perubahan (Lee \& Byun, 2012). Berdasarkan hal itu, konsep awal yang dimiliki oleh siswa sebelum belajar akan suatu materi pelajaran dalam IPA memiliki andil sebagai faktor penyebab miskonsepsi. Selain itu, miskonsepsi yang dipegang oleh siswa dengan keyakinan yang tinggi akan sulit untuk diperbaiki baik oleh praktisi maupun akademisi. Terakhir, penggunaan kata miskonsepsi digunakan dalam penelitian ini karena mengacu pada kesalahpahaman siswa akan konsep yang ilmiah.

Masalah miskonsepsi dan pemahaman konsep yang rendah adalah masalah yang banyak terjadi dalam pembelajaran fisika. Berbagai penelitian menunjukkan bahwa miskonsepsi terjadi pada hampir semua topik fisika (Mufit, Festiyed, Fauzan, \& Lufri, 2018). Seperti dalam penelitian (Pine, Messer, \& John, 2001) yang mengidentifikasi beberapa miskonsepsi siswa tentang materi listrik, gaya dan gerak, cahaya, dan suara: (a) Pada submateri listrik, kasus seperti siswa yang kesulitan memahami bahwa lemari es menggunakan listrik, kesulitan memahami listrik sebagai sebuah gaya yang dikatakan tidak terlihat, atau bahkan dipahami sebagai obyek yang terbungkus sesuatu; (b) Pada submateri tenggelam dan terapung, dilaporkan kasus seperti siswa yang memahami bahwa benda yang besar pasti tenggelam dan benda yang kecil pasti terapung, sealin itu juga siswa

Yogi Kuncoro Adi, Miskonsepsi Siswa SD Pada Materi Physical Processes: Sebuah Studi Kasus 
percaya bahwa benda yang berat akan tenggelam dan benda yang ringan akan terapung; (c) Pada submateri berat dan ukuran, didapatkan laporan bahwa siswa meyakini benda padat yang berukuran besar pasti lebih berat daripada benda padat yang berukuran lebih kecil, selain itu juga dilaporkan siswa yang percaya bahwa benda berat akan terjun dengan kecepatan yang lebih cepat dibanding benda ringan pada ketinggian yang sama ketika dijatuhkan; (d) Pada submateri sumber cahaya, kasus ditemukan pada siswa yang percaya bahwa mereka dapat menyalakan lampu ketika diletakkan di matahari, siswa yang percaya bahwa lampu adalah sumber cahaya utama manusia, bulan adalah sumber cahaya, matahari mengelilingi Bumi, matahari berbalik lalu berubah menjadi bulan ketika malam hari, cahaya berasal dari langit dan bukan dari matahari, terang dan gelap dianalogikan sebagai menyala dan mematikan lampu, dan terakhir kasus siswa yang memahami bahwa matahari turun dari langit ketika terbenam di sore hari; (e) Pada submateri bayangan, siswa memahami bahwa bayangan dapat terjadi antara matahari dan benda, bayangan akan selalu mengikuti obyek, dan siswa yang kebingungan akan perbedaan refleksi dan bayangan; (f) Pada submateri suara, kasus dilaporkan tentang siswa yang kesulitan memahami bahwa suara diproduksi atau berasal dari getaran dan berjalan sebagai gelombang.

Penelitian ini merupakan identifikasi untuk mengungkap jenis miskonsepsi siswa SD yang mengacu pada materi IPA dasar (Allen, 2010) khususnya Physical processes, yaitu pada submateri: gaya, terapung dan tenggelam, listrik dan magnet, cahaya, suara, Bumi dan angkasa, serta panas. Studi kasus ini menjadi upaya untuk memperdalam pengetahuan dalam pemahaman konseptual dengan mengkonfirmasi alasan jawaban siswa. Akhirnya, hasil penelitian ini diharapkan dapat menyiapkan para praktisi dan akademisi terkait kasus yang serupa dalam pembelajaran IPA di tingkat SD.

\section{METODE PENELITIAN}

Studi kasus yang dijadikan fokus kajian adalah masalah miskonsepsi siswa sekolah dasar dalam materi pelajaran IPA, difokuskan pada materi Physical processes. Siswa di SD N 2 Purwawinangun, SD N 1 Awirarangan, dan SD N Unggulan yang berada di wilayah UPT Dinas Pendidikan Kabupaten Kuningan 
dilibatkan sebagai subjek dalam penelitian ini. Data tentang jenis miskonsepsi IPA didapatkan sumber datanya dari siswa. Penulisan secara inisial nama disertai dengan jenjang kelas, misalnya MFF (3), digunakan dalam penelitian ini untuk menjaga kerahasiaan. Teknik pengumpulan data yang digunakan adalah pengamatan dan wawancara. Pengamatan dilakukan dengan mengamati proses kegiatan pembelajaran di dalam kelas. Melalui teknik tersebut, didapatkan beberapa siswa untuk diwawancara karena terindikasi mengalami miskonsepsi, sehingga peneliti ingin mengungkapnya lebih dalam. Analisis data dalam penelitian ini menggunakan teknik untuk penelitian kualitatif dari Miles \& Huberman (Sugiyono, 2011), yaitu data reduction, data display, dan conclusion drawing/verification. Triangulasi dilakukan dengan cara mengumpulkan data dengan teknik pengumpulan data yang berbeda (pengamatan dan wawancara), mengkonfirmasi miskonsepsi siswa dalam waktu dan situasi yang berbeda, serta siswa yang berbeda.

\section{HASIL DAN PEMBAHASAN PENELITIAN}

\section{Hasil Penelitian}

Para siswa yang didapatkan melalui kegiatan pengamatan kemudian diberikan pertanyaan langsung (ask pupils directly about their ideas) tentang konsep gaya, terapung dan tenggelam, listrik dan magnet, cahaya, serta Bumi dan angkasa dalam sesi wawancara tidak terstruktur. Beberapa siswa memberikan jawaban yang tidak ilmiah namun diyakini benar oleh mereka. Melalui studi kasus ini, ditemukan miskonsepsi yang terjadi pada siswa baik kelas rendah maupun kelas tinggi. Deskripsi hasil penelitian tersebut disajikan sebagai berikut.

Kasus miskonsepsi pertama ditemukan pada siswa yang membedakan seberapa berat benda dibanding lainnya, dalam hal ini adalah $1 \mathrm{~kg}$ beras dibanding dengan $1 \mathrm{~kg}$ kapas. Siswa BS (3) menjawab lebih berat beras. Hal yang sama juga disebutkan oleh MFF (3) bahwa $1 \mathrm{~kg}$ beras lebih berat dibanding dengan $1 \mathrm{~kg}$ kapas. Siswa tersebut meyakini bahwa dalam hal apapun kapas selalu memiliki bobot yang ringan. Kasus berikutnya ditemukan pada satu siswa yang menyebutkan bahwa gaya harus menjadikan suatu benda bergerak. MABA 
(1) menyatakan hal itu hanya karena benda tersebut diam saja, bukan dikarenakan dipengaruhi oleh gaya tertentu.

Tabel 1. Miskonsepsi Siswa SD pada Materi Gaya

\begin{tabular}{lll}
\hline No & Jenis Miskonsepsi & \multicolumn{1}{c}{ Kasus } \\
\hline 1 & $\begin{array}{l}\text { Membedakan seberapa } \\
\text { berat benda dibanding } \\
\text { lainnya }\end{array}$ & $\begin{array}{l}\text { Lebih berat } 1 \mathrm{~kg} \text { beras dibanding } \\
\text { dengan 1 kg kapas }\end{array}$ \\
\cline { 3 - 3 } & & $\begin{array}{l}\text { Kapas selalu memiliki bobot yang } \\
\text { ringan }\end{array}$ \\
2 & $\begin{array}{l}\text { Gaya harus menjadikan } \\
\text { suatu benda bergerak }\end{array}$ & $\begin{array}{l}\text { Benda diam karena tidak terkena } \\
\text { gaya }\end{array}$
\end{tabular}

Jenis miskonsepsi selanjutnya berkaitan dengan konsep terapungtenggelam. Beberapa siswa meyakini bahwa konsep tenggelam dimiliki oleh benda yang berat. Seperti MGHA (2) yang melaporkan bahwa benda yang berat dapat tenggelam dalam air. Siswa tersebut mencontohkan batu dan kapal di laut. Kedua benda tersebut, menurutnya, akan tenggelam dalam air karena memiliki bobot yang berat. Pun demikian juga dengan APR (3), namun mencontohkan benda beratnya adalah kelereng. Berbeda dengan kasus itu, kasus berikut memberikan perluasan makna terhadap benda yang berat sehingga tidak tenggelam dalam air. SNMH (3) menyatakan bahwa perahu tidak tenggelam dalam air meskipun memiliki bobot yang berat. Hal tersebut dikarenakan, lanjutnya, perahu selalu bergerak. Namun jika perahu tersebut bocor maka akan tenggelam dalam air. Kasus terakhir dari indikator ini adalah berkaitan dengan konsep terapung. JNR (1) memberi pernyataan bahwa benda kecil selalu terapung di permukaan air. Hal tersebut diyakininya karena benda kecil pasti selalu ringan, misalnya daun, disebutkan.

Tabel 2. Miskonsepsi Siswa SD pada Materi Terapung-Tenggelam

\begin{tabular}{llllll} 
No & \multicolumn{2}{l}{ Jenis Miskonsepsi } & \multicolumn{2}{l}{ Kasus } \\
& & & & \\
\hline $\mathbf{1}$ & Konsep & tenggelam & Batu dan kapal di laut dapat
\end{tabular}




\begin{tabular}{|c|c|c|}
\hline & \multirow{2}{*}{$\begin{array}{l}\text { dimiliki oleh benda yang } \\
\text { berat }\end{array}$} & \multirow{2}{*}{$\begin{array}{l}\text { tenggelam dalam air karena berat } \\
\text { Kelereng juga berat sehingga } \\
\text { tenggelam dalam air }\end{array}$} \\
\hline & & \\
\hline 2 & $\begin{array}{l}\text { Benda yang berat tidak } \\
\text { selalu tenggelam dalam } \\
\text { air }\end{array}$ & $\begin{array}{l}\text { Perahu tidak tenggelam dalam air } \\
\text { meskipun berbobot berat, } \\
\text { dikarenakan perahu selalu bergerak }\end{array}$ \\
\hline 3 & $\begin{array}{l}\text { Benda kecil selalu } \\
\text { terapung di permukaan } \\
\text { air }\end{array}$ & $\begin{array}{l}\text { Benda kecil pasti selalu ringan } \\
\text { bobotnya }\end{array}$ \\
\hline
\end{tabular}

Miskonsepsi pada indikator materi cahaya berkaitan dengan warna. Kasus pertama ditemukan pada beberapa siswa yang menyebutkan warna pelangi dengan jumlah yang beraneka ragam. AF (1) menyebutkan warna pelangi ada 4, yaitu merah, kuning, hijau, dan biru. MFF (3) menyebutkan ada 6, yaitu kuning, hijau, oranye, biru, merah, dan hijau tua. Sedangkan MRZ menyebutkan ada 5, yaitu merah, biru, kuning, oranye, dan hijau. Selain kasus tersebut, beberapa siswa juga menyatakan bahwa bentuk pelangi itu adalah setengah lingkaran. MFF (3) menyebutkan bahwa bentuk dari pelangi adalah setengah lingkaran. Demikian halnya MRZ (5) yang melaporkan bahwa bentuk pelangi adalah melengkung.

Tabel 3. Miskonsepsi Siswa SD pada Materi Cahaya

\begin{tabular}{lll} 
No & Jenis Miskonsepsi & Kasus \\
\hline $\mathbf{1}$ & $\begin{array}{l}\text { Pelangi memiliki kurang } \\
\text { dari tujuh warna }\end{array}$ & $\begin{array}{l}\text { Warna pelangi ada 4, yaitu merah, } \\
\text { kuning, hijau, dan biru }\end{array}$ \\
\cline { 2 - 2 } & $\begin{array}{l}\text { Ada 6, yaitu kuning, hijau, oranye, } \\
\text { biru, merah, dan hijau tua }\end{array}$ \\
& Ada 5, yaitu merah, biru, kuning, \\
& oranye, dan hijau
\end{tabular}

2 Bentuk pelangi itu Bentuk pelangi setengah lingkaran 
Miskonsepsi pada materi listrik hanya ditemukan dua kasus sedangkan magnet satu kasus. Kasus pertama dilaporkan mengenai perubahan energi listrik menjadi bentuk energi lain yang tidak ilmiah. Siswa ARG (5) menyebutkan bahwa energi listrik yang diterima oleh kulkas diubah menjadi energi dingin. Hal itulah yang menyebabkan benda-benda yang berada di dalam kulkas menjadi dingin dibanding di luar kulkas. Miskonsepsi lain ditemukan pada siswa MABA (1) bahwa seseorang dapat melihat listrik dalam aliran. Siswa yang mempercayai bahwa listrik mengalir dalam kabel tersebut juga melaporkan bahwa seseorang mampu melihat listrik. Namun, siswa tersebut juga melaporkan cara melihatnya adalah dengan membuka aliran listrik dalam kabel. Selain itu, siswa yang sama menyatakan pula bahwa magnet memiliki gaya menempel pada besi. Namun, MABA (1) melanjutkan, ketika magnet didekatkan dengan magnet maka tidak bisa menempel.

Tabel 4. Miskonsepsi Siswa SD pada Materi Listrik dan Magnet

\begin{tabular}{|c|c|c|}
\hline No & Jenis Miskonsepsi & Kasus \\
\hline 1 & $\begin{array}{l}\text { Perubahan energi } \\
\text { menjadi energi lain }\end{array}$ & $\begin{array}{l}\text { Kulkas adalah benda yang } \\
\text { mengubah energi listrik menjadi } \\
\text { energi dingin }\end{array}$ \\
\hline 2 & $\begin{array}{lr}\text { Seseorang } & \text { dapat } \\
\text { melihat listrik } & \text { dalam } \\
\text { aliran kabel } & \end{array}$ & $\begin{array}{l}\text { Jika kabel dibuka maka kita akan } \\
\text { dapat melihat aliran listrik }\end{array}$ \\
\hline 3 & $\begin{array}{l}\text { Magnet memiliki gaya } \\
\text { menempel }\end{array}$ & $\begin{array}{l}\text { Magnet dapat menempelkan besi, } \\
\text { namun ketika magnet didekatkan } \\
\text { dengan magnet maka tidak bisa } \\
\text { menempel }\end{array}$ \\
\hline
\end{tabular}


Beberapa siswa beranggapan bahwa matahari cahayanya padam ketika malam hari. Kasus tersebut terjadi pada AF (1) dan MFF (3). AF (1) memiliki miskonsepsi bahwa matahari hanya bersinar pada siang hari saja. Siswa tersebut berkeyakinan demikian karena berpikir bahwa ketika malam hari tiba maka matahari digantikan oleh bulan. MFF (3) meyakini bahwa matahari tidak mungkin bersinar ketika malam hari. Hal tersebut dia percayai karena suasana gelap di malam hari disebabkan oleh padamnya cahaya matahari.

Beberapa siswa lain, yaitu ADN (2), MGHA (2), dan MABA (1) meyakini bahwa matahari tidak terlihat ketika malam hari tiba selain mungkin disebabkan oleh padamnya sinar juga karena tertutup oleh benda lainnya. ADN (2) menganggap bahwa ketika malam tiba bulan menutupi matahari. Meskipun begitu, dia yakin bahwa matahari tetap tidak bersinar jika tidak sedang tertutup oleh bulan. Hal yang sama juga terjadi pada MGHA (2), yang mana dia juga menguatkan konsepsinya berdasarkan pengamatannya saat malam hari. Sedangkan MABA (1) memiliki konsepsi dengan alasan yang agak berbeda dibanding dengan dua lainnya. Siswa ini menganggap bahwa matahari tetap bersinar sepanjang hari, namun ketika malam hari matahari terhalang oleh awan sehingga tidak terlihat sinarnya.

Jenis miskonsepsi selanjutnya dimiliki oleh beberapa siswa, ARG (5), AF (3), DAP (1), RS (5), JNR (1), dan PCA (3), yang mana memiliki konsepsi bahwa matahari bergerak pada fenomena siang dan malam. ARG (5) memiliki konsepsi bahwa matahari ketika menjelang malam hari tiba akan bergerak turun ke Bumi. Begitu pula yang terjadi pada pagi hari matahari muncul dengan cara naik ke atas. Siswa ini mengetahui bahwa Bumi itu berputar pada porosnya, namun tetap beranggapan bahwa matahari pun juga ikut bergerak pada fenomena tersebut. AF (3) memiliki konsepsi yang sama, bahwa matahari lah yang bergerak pada peristiwa siang dan malam. Siswa ini menganggap bahwa matahari mampu bergerak dengan cara berpindah ke tempat yang lain. DAP (1) berkeyakinan bahwa ketika malam hari tiba maka matahari tidak bersinar. Dia meyakini bahwa matahari tersebut tenggelam di suatu tempat. Hal yang sama juga terjadi pada RS (5) dan PCA (3) dengan alasan yang sama bahwa matahari bergerak turun ke bawah (tenggelam) ketika menjelang malam hari kemudian posisinya digantikan 
oleh bulan. Sedangkan JNR (1) memiliki alasan yang sedikit berbeda, yaitu bahwa matahari pergi menuju tempat asalnya ketika malam hari tiba. Ditambahkan bahwa tempat asal matahari adalah berada di langit.

Miskonsepsi tentang bulan yang memancarkan cahayanya sendiri ditemukan pada satu kasus yaitu DAP (1). Siswa ini menyatakan bahwa bulan mampu memancarkan cahayanya sendiri seperti bintang.

Miskonsepsi tentang ukuran benda angkasa ditemukan pada satu kasus yaitu RS (5). Siswa tersebut meyakini bahwa ukuran Bumi lebih besar daripada matahari dan ukuran matahari lebih besar daripada bulan. Urutan ukuran Bumi, matahari, bulan secara berurutan dipahami oleh siswa karena Bumi sebagai benda yang paling besar mampu menampung manusia yang sedemikian banyaknya.

Terakhir, miskonsepsi mengenai matahari bukanlah bintang ditemukan pada ARG (5). Siswa tersebut mengatakan bahwa matahari dan bintang adalah dua benda angkasa yang berbeda. Dia beralasan bahwa cahaya yang dipancarkan oleh matahari lebih terang daripada cahaya yang dipancarkan oleh bintang. Selain itu, dia juga beralasan bahwa perbedaan tersebut tidak hanya mencakup seberapa terang cahayanya. Akan tetapi, bentuk dari matahari dan bintang pun juga berbeda. Siswa ini mengaku membutuhkan penggaris berpola untuk dapat mencetak gambar bintang (pentagram) ketika diminta untuk menggambarkan seperti apa bentuk bintang itu.

Tabel 5. Miskonsepsi Siswa SD pada Materi Bumi dan Angkasa

\begin{tabular}{|c|c|c|}
\hline No & Jenis Miskonsepsi & Kasus \\
\hline 1 & $\begin{array}{l}\text { Cahaya matahari } \\
\text { padam saat malam hari }\end{array}$ & $\begin{array}{l}\text { Matahari digantikan bulan saat } \\
\text { malam hari }\end{array}$ \\
\hline & & $\begin{array}{l}\text { Suasana gelap di malam hari } \\
\text { karena cahaya matahari padam }\end{array}$ \\
\hline 2 & $\begin{array}{l}\text { Benda lain menutupi } \\
\text { matahari saat malam } \\
\text { hari }\end{array}$ & $\begin{array}{l}\text { Tertutup oleh bulan } \\
\text { Terhalang oleh awan }\end{array}$ \\
\hline
\end{tabular}




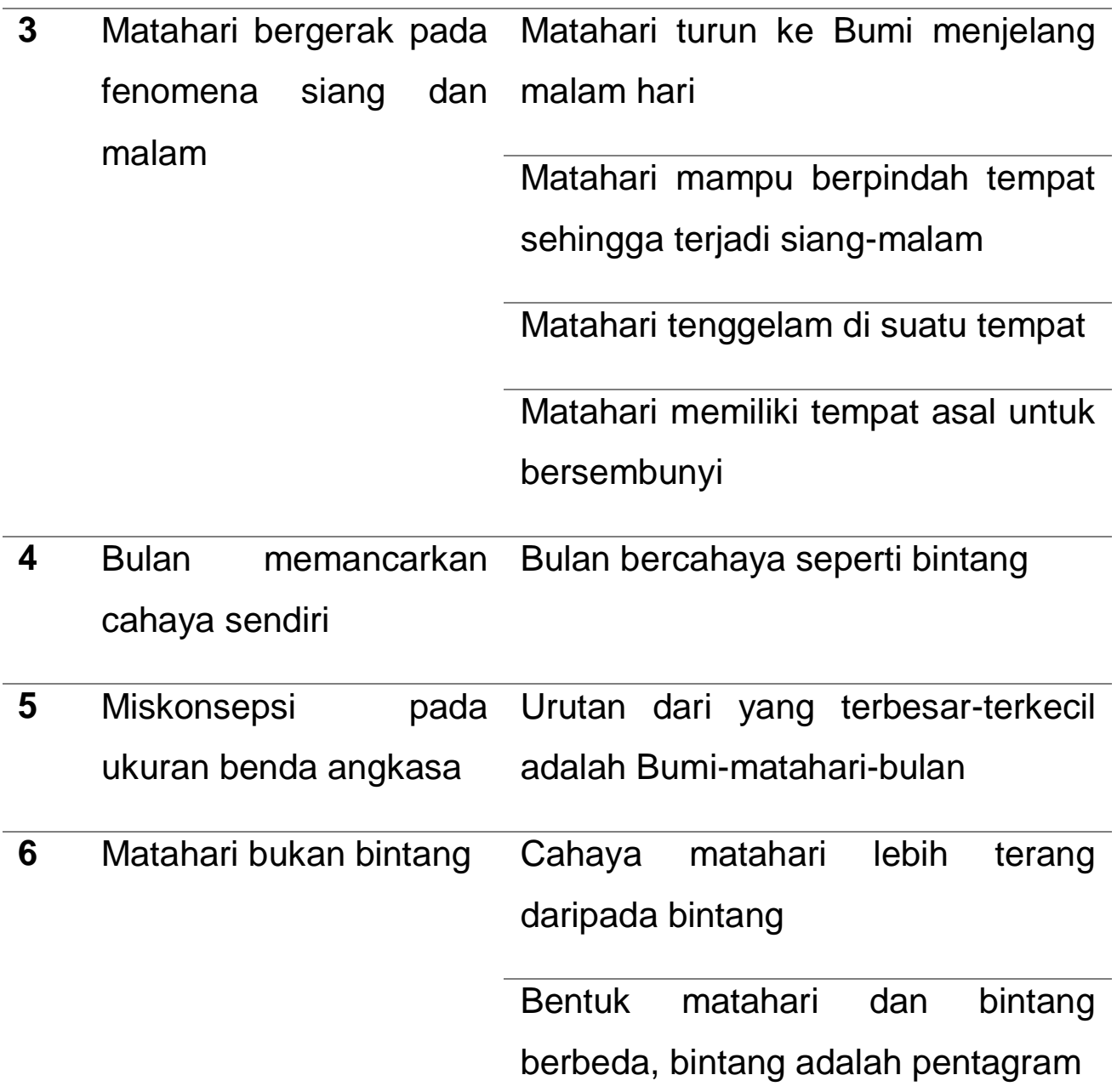

\section{Pembahasan}

Penelitian ini menemukan miskonsepsi siswa SD pada materi Physical processes yang terbentang ke berbagai submateri, yaitu gaya, terapungtenggelam, cahaya, listrik dan magnet, serta Bumi dan angkasa. Siswa pun memiliki miskonsepsi yang tersebar dari ke-tiga sekolah dasar dan dari berbagai jenjang kelas. Hal tersebut sesuai dengan pernyataan (Suparno, 2013) bahwa miskonsepsi terdapat dalam semua bidang sains, misalnya fisika, dan miskonsepsi juga menghinggapi semua level siswa mulai dari siswa sekolah dasar sampai dengan mahasiswa.

Berdasarkan temuan penelitian, disini peneliti menyajikan anomali berupa konsep ilmiah yang bertentangan dengan konsep siswa (miskonsepsi). Pada materi gaya, berat benda yang memiliki jumlah satuan sama adalah sama, $1 \mathrm{~kg}$ beras sama dengan $1 \mathrm{~kg}$ kapas beratnya, meskipun jenis benda berbeda namun 
satuan standar baku sudah teruji valid dan reliabel-nya. Gaya adalah dorongan dan/atau tarikan, yang berarti tidak mensyaratkan adanya pergerakan, sehingga benda diam pun juga disebabkan oleh gaya (resultan gaya nol), misalnya buku yang diletakkan di atas meja yang diam karena terkena gaya gravitasi.

Pada materi terapung-tenggelam, fenomena terapung dan tenggelam bukanlah disebabkan oleh berat benda, namun massa jenis. Benda yang memiliki massa jenis lebih kecil dibanding air akan terapung sedangkan benda yang memiliki massa jenis lebih besar dibanding air akan tenggelam. Begitu pun halnya benda yang berukuran kecil, tidak selalu terapung atau tenggelam dalam air. Artinya, sebuah kapal yang memiliki berat hingga beberapa ton pun dapat terapung karena memiliki rongga udara yang cukup besar pada sebagian tubuhnya, sehingga membuat massa jenisnya lebih kecil dari air di lautan.

Pada materi cahaya, pembahasan adalah mengenai pelangi yang memiliki tujuh warna yang disebabkan oleh dispersi (penguraian cahaya) matahari oleh titik-titik hujan. Warna cahaya matahari yang bersifat polikromatik dapat terurai menjadi merah, jingga, kuning, hijau, biru, nila, dan ungu. Selain itu, bentuk asli dari pelangi adalah lingkaran, yang mana kita sering melihatnya sebagai setengah lingkaran saja dikarenakan posisi pandang kita.

Pada materi listrik dan magnet, pembahasan mengenai listrik berkaitan dengan perubahan wujud energi pada kulkas. Energi kalor berperan dalam hal itu (kalor bukan berarti panas). Energi tersebut mengalir dari potensial tinggi ke potensial rendah, artinya dapat berdampak panas atau dingin pada suatu benda. Selain itu, konsep kelistrikan pada kabel adalah listrik dinamis (berjalan dalam aliran kabel), sehingga kita tidak bisa melihat bentuk listriknya. Jika kabel tersebut dibuka maka listrik tidak akan mengalir, karena kita membuat rangkaian terbuka, sehingga mustahil untuk melihatnya. Listrik merupakan konsep yang cukup sulit dipahami oleh siswa karena bentuknya yang abstrak, namun dampaknya dapat terlihat. Berkaitan dengan magnet, magnet adalah benda yang dapat memberikan gaya jenis dorongan dan tarikan sekaligus. Misalnya, dorongan adalah ketika dua buah magnet dengan dua kutub yang sama didekatkan sedangkan tarikan adalah ketika dua buah magnet dengan dua kutub yang berbeda didekatkan. 
Pada materi Bumi dan angkasa, fenomena siang dan malam merupakan dampak dari rotasi Bumi, sehingga ada belahan Bumi yang terkena siang hari dan sebagian lagi malam hari. Matahari, adalah bintang, sehingga bersinar sepanjang waktu dan tidak pernah padam meskipun juga terhalang oleh benda lain di angkasa. Cahaya matahari lebih terang dibanding cahaya bintang karena matahari-lah bintang terdekat dengan planet Bumi kita, sedangkan bintangbintang lain yang terlihat pada malam hari letaknya sangat jauh. Kemudian ukuran benda angkasa yang terbesar hingga terkecil adalah matahari-Bumi-bulan (hanya tiga benda itu yang ditanyakan dalam sesi wawancara).

Sajian pembahasan konsep ilmiah dari miskonsepsi tersebut di atas merupakan data anomali yang menjadi bagian dari strategi konflik kognitif dalam perubahan konseptual. Piaget (Tippett, 2010) menyebutkan bahwa siswa memahami dunia dari perspektif struktur pengetahuan yang dikembangkan mereka (skema), yang diadaptasi selama asimilasi atau akomodasi. Asimilasi terjadi ketika informasi atau konsep baru dapat ditambahkan tanpa merestrukturisasi skema yang ada (pertumbuhan konseptual) sedangkan akomodasi terjadi ketika skema harus direstrukturisasi untuk memasukkan informasi atau konsep baru (perubahan konseptual).

Perubahan konseptual dapat dilakukan dengan menggunakan tiga jenis strategi instruksional seperti: (a) induksi konflik kognitif melalui data anomali; (b) penggunaan analogi untuk membimbing perubahan siswa; dan (c) pembelajaran kooperatif dan berbagi untuk mempromosikan diskusi ide secara kolektif (Limón, 2001). Oleh karena itu, sejalan dengan dukungan literatur tersebut di atas, penggunaan data anomali dalam konflik kognitif merupakan salah satu strategi bagi praktisi atau akademisi yang berkecimpung dalam pembelajaran IPA untuk memperbaiki miskonsepsi yang ada dalam kelas mereka. Namun, (Burgoon, Heddle, \& Duran, 2011) perlu menjadi perhatian bahwa guru yang tidak menyadari atau meremehkan pentingnya miskonsepsi tidak mungkin memberikan bimbingan yang dibutuhkan siswa untuk perubahan konseptual. Artinya, pengetahuan konten guru juga memainkan peran besar dalam fasilitasi strategi perubahan konseptual.

\section{SIMPULAN}


Konstruktivisme merupakan salah satu mazhab yang sering digunakan dalam pembelajaran IPA, yang menganggap bahwa siswa dipandang sebagai peserta aktif dalam perolehan keterampilan dan pengetahuan. Oleh karena itu, dalam penelitian ini ditemukan kasus siswa-siswa yang memiliki miskonsepsi karena kekeliruan dalam memahami suatu konsep ilmiah. Miskonsepsi yang ditemukan dalam penelitian ini meliputi siswa-siswa yang meyakini konsep tenggelam dimiliki oleh benda yang berat, benda yang berat tidak selalu tenggelam dalam air karena bergerak, benda kecil selalu terapung di permukaan air, pelangi memiliki kurang dari tujuh warna, bentuk pelangi itu adalah setengah lingkaran, perubahan energi listrik menjadi energi dingin pada kulkas, seseorang dapat melihat listrik dalam aliran kabel, magnet memiliki gaya menempel, cahaya matahari padam saat malam hari, benda lain menutupi matahari saat malam hari, matahari bergerak pada fenomena siang dan malam, bulan memancarkan cahaya sendiri, miskonsepsi pada ukuran benda angkasa, dan bahwa matahari bukanlah bintang.

Berdasarkan simpulan tersebut, disarankan adanya penelitian lanjutan untuk memperdalam bagaimana siswa belajar, artinya proses belajar siswa yang mampu mengungkap perkembangan belajarnya. Langkah selanjutnya adalah para praktisi dan/atau akademisi yang berkecimpung dalam pembelajaran IPA dapat menggunakan strategi perubahan konseptual, misalnya konflik kognitif, untuk meremidiasi miskonsepsi yang dimiliki siswa. Terakhir, penelitian ini bukan berupaya menggeneralisir namun mengungkap detail jenis miskonsepsi siswa sehingga diharapkan dapat dijadikan khazanah pengetahuan.

\section{DAFTAR PUSTAKA}

Allen, M. (2010). Misconceptions in Primary Science. New York: Open University Press. Burgoon, J. N., Heddle, M. L., \& Duran, E. (2011). Re-Examining the Similarities Between Teacher and Student Conceptions About Physical Science. Journal of Science Teacher Education, 22(2), 101-114. https://doi.org/10.1007/s10972-0109196-x

Celikten, O., Ipekcioglu, S., Ertepinar, H., \& Geban, O. (2012). The Effect of the Conceptual Change Oriented Instruction through Cooperative Learning on 4th Grade Students' Understanding of Earth and Sky Concepts. Science Education International, 23(1), 84-96.

Lee, G., \& Byun, T. (2012). An Explanation for the Difficulty of Leading Conceptual 
Change Using a Counterintuitive Demonstration: The Relationship Between Cognitive Conflict and Responses. Research in Science Education, 42(5), 943-965. https://doi.org/10.1007/s11165-011-9234-5

Limón, M. (2001). On the cognitive conflict as an instructional strategy for conceptual change: A critical appraisal. Learning and Instruction, 11(4-5), 357-380. https://doi.org/10.1016/S0959-4752(00)00037-2

Mufit, F., Festiyed, F., Fauzan, A., \& Lufri, L. (2018). Impact of Learning Model Based on Cognitive Conflict toward Student's Conceptual Understanding. IOP Conference Series: Materials Science and Engineering, 335(1). https://doi.org/10.1088/1757899X/335/1/012072

Pine, K., Messer, D., \& John, K. St. (2001). Children's Misconceptions in Primary Science: A survey of teachers' views. Research in Science \& Technological Education, 19(1), 79-96. https://doi.org/10.1080/0263514012004624

Sugiyono. (2011). Metode penelitian kuantitatif kualitatif dan $r \& d$. Bandung: Afabeta.

Suparno, P. (2013). Miskonsepsi \& perubahan konsep dalam pendidikan fisika. Jakarta: PT Grasindo.

Tippett, C. D. (2010). Refutation Text In Science Education: A Review Of Two Decades Of Research. International Journal of Science and Mathematics Education, 8(6), 951-970. https://doi.org/10.1007/s10763-010-9203-x

Zhou, G. (2010). Conceptual change in science: A process of argumentation. Eurasia Journal of Mathematics, Science and Technology Education, 6(2), 101-110. https://doi.org/10.12973/ejmste/75231 